\title{
U.S. Trade In Goods With Latin America (2001-2010): Trends And Perspectives
}

Rutilio Martinez, University of Northern Colorado, USA Vish Iyer, University of Northern Colorado, USA

\begin{abstract}
Between 2001 and 2010, U.S. trade in goods with Latin America grew at an unprecedented 7.04\% per year. However, during these years, mostly as a consequence of the rapid growth of trade between China and Latin America, the relative importance of the U.S. as a trading partner of Latin America declined significantly. Projections indicate that, although trade between the U.S. and Latin America will grow, this decline is very likely to continue, thereby contributing to the erosion of U.S. influence on this region of the world.
\end{abstract}

Keywords: Trade; Exports; Imports; Trading Partner; Rate of Growth; Latin America

\section{INTRODUCTION}

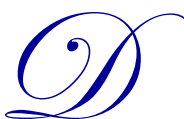

uring the period 2001-2010, U.S. trade in goods with Latin America grew at an annual average rate of $7.04 \%$, from $\$ 345.3$ billion in 2001 to $\$ 636.7$ billion in 2010 . This rate was double the average rate of growth of Latin America's GDP and one percentage point higher than the average rate of growth of total U.S. trade in goods between 2001 and 2010. Nonetheless, the proportion of U.S. goods in Latin American imports went from $44 \%$ in 2001 to $35.7 \%$ in 2010, while the proportion of Latin American exports that went to the U.S. dropped from 56\% in 2001 to barely over $40 \%$ in 2010. Additionally, the U.S. trade deficit with Latin America went from $\$ 39.5$ billion in 2001 to $\$ 64.5$ billion in 2010 (U.S. Census Bureau, 2011, and Economic Commission for Latin America and the Caribbean [ECLAC], 2010).Thus, even though trade in goods between the U.S. and Latin America grew at an unprecedented high rate between 2001 and 2010, the U.S. trade deficit with this region increased at the same time that the relative importance of the U.S. as a trading partner of Latin America declined.

This decline was primarily caused by the large increase in China-Latin America trade. China's trade with Latin America did not, however, displace in a significant way trade between the U.S. and Latin America. Such displacement did not occur because China's exports to Latin America were dominated by goods that, for decades, have not been produced in significant quantities in the U.S, while China's imports from Latin American have been dominated by primary goods, which the Latin nations were able to produce in sufficient quantities to easily satisfy the demands from local and international markets (Kay and Canavire-Bacarreza, 2011).

As the U.S. economy continues recovering, U.S. imports from Latin America are likely to continue growing. There are, however, two factors that are very likely to render such potential growth insufficient to stop the decline of the relative importance of the U.S. as importer of Latin American goods. These are: 1) a projected growth of China's GDP that is 2.5 to 4.5 percentage points higher than the projected growth of the GDP of the U.S. and 2) the very limited capacity of the Latin countries to produce the kind of high-income goods that are demanded by the U.S. economy (Kay and Canavire-Bacarreza, 2011; U.S. Government Printing Office [GPO], 2011; and ECLAC, 2010).

As exporter of goods to Latin America, the U.S. has good prospects of reversing the decline of its relative importance as long as the Latin American nations continue adopting polices that promote growth. These prospects may, however, be limited, or even eliminated, by factors such as the growing presence of goods from Europe and Japan in Latin American markets and the disdain of Latin America across U.S. society (Eurostat, 2011, and Coelen, 1998). 
In the past, the U.S. considered Latin America as its backyard, where its political and economic influence was easily exercised through a variety of channels, one being, of course, trade in goods. Hence, as the relative importance of the U.S. as a trading partner of Latin America declines, this influence will erode (Hornbeck, 2010). Such erosion, however, is likely to be marginal in the nations that send a large number of immigrants to the U.S, such as Mexico, Colombia and most of the Central American nations; but in the other Latin nations, where U.S. influence is already diminishing, this erosion is likely to be significant.

The next two sections discuss the 2001-2010 trends and prospects for the near future of U.S. imports from and exports to Latin America, respectively, followed by a discussion dealing with potential implications of the projected decline in the relative importance of the U.S. as a trading partner of Latin America, and lastly, conclusions.

\section{IMPORTS FROM LATIN AMERICA}

U.S. imports of goods from Latin America grew between 2001 and 2010 at a yearly average rate of $6.7 \%$ from $\$ 192.4$ billion in 2001 to $\$ 350.6$ billion in 2010. All 19 nations of Latin America participated in this high and unprecedented growth which meant that by 2010 , every single Latin American country was exporting more to the U.S. than in 2001 (U.S. Census Bureau, 2011).

Yet, between 2001 and 2010, the U.S. ceased to be the largest buyer or importer of goods from an increasing number of Latin nations. In 2001, the U.S. was not the main buyer or importer for Argentina, Cuba, Paraguay and Uruguay. By 2010, this group was joined by Bolivia, Brazil, Chile and Panama; that is, between 2001 and 2010, the number of Latin countries for which the U.S. was not the main importer of their goods went from four to eight (ECLAC 2010).

Along with the increase in the number of Latin nations for which the U.S. was not the number one importer came the reduction in the percentage or share of Latin American exports that went to the U.S. This percentage progressively declined between 2001 and 2010 - from 56\% to 39.5\% (ECLAC, 2010). Thus, despite the 6.7\% annual growth rate of U.S. imports from Latin America during the period 2001-2010, the relative importance of the U.S. as importer of Latin American goods underwent a steady and marked decline.

The main cause of this decline was the fast increase of Latin American exports to China. These exports grew 32.5\% per year during this period - from $\$ 5.4$ billion dollars in 2001 to at least $\$ 68.7$ billion in 2010. Due to this high growth, China went from being (in 2001) an importer of very marginal importance for the Latin American nations to being (in 2010) the number one importer for Brazil, Chile, Cuba and Peru, and the number two importer for Argentina, Costa Rica and Venezuela. Also as a result of the high growth of their exports to China, Argentina, Brazil, Chile and Peru were - of all the 19 Latin American nations - the first ones to recover from the recession that afflicted many countries between 2007 and 2009 (Kay and Canaveri-Bacarreza, 2011; and Central Intelligence Agency [CIA], 2011)

China's imports from Latin America grew so much during the period 2001-2010 because China's economy grew at an annual rate of $10.2 \%$ during these years (Kay and Canaveri-Bacarreza, 2011). Thus, if the direct correlation between the growth of China's economy and its imports from Latin American continues, the projected five to seven percent yearly growth of China's GDP for the 2012-2016 period should result in a significant reduction of the rate of growth of Latin American exports to China. Very likely, this reduction may not, however, be enough to allow the U.S. to reverse - or at least to stop - the decline of its relative importance as importer of Latin American goods. Two obstacles preclude such a reversal.

The first of these obstacles is the slow - current and projected - growth of the U.S. economy. In 2011, the U.S. economy grew less than two percent and for the period 2012-2017, the U.S. economy is projected to expand at no more than 2.5 percent per year (U.S. Government Printing Office, 2011). Therefore, the U.S. economy is growing and is expected to grow at rates that are no more than one-half of the projected rates of China's growth in economy. Such differential practically guarantees that the rate of growth of imports from Latin America is bound to be significantly smaller for the U.S. than for China for the next four years. 
The second of these obstacles is the limited capacity of Latin America to produce high-income goods. This limitation is indicated by the dominance of Mexico in the exports of these products to the U.S. Between 2001 and 2010, Latin American exports to China were almost exclusively primary goods; while manufactured goods were, on average, $60 \%$ of the Latin American exports to the U.S. Of this 60\%, however, at least $90 \%$ consisted of cars, complex chemical inputs, high-tech electronics, components of high-tech machinery, and other high-income goods made or assembled in Mexico (Kay and Canaveri-Bacrreza, 2011, and Banco de Mexico, 2011).

These exports were assembled or manufactured in the industrial plants of Mexico's export-of-manufactures sector. The vast majority of these plants belong to companies from the U.S., some belong to European, Japanese and Korean companies, and very few belong to Indian and Chinese companies. These companies established production and assembling plants in Mexico to take advantage of the country's abundant cheap labor, proximity to U.S. markets, and the legal structure provided by the North American Free Trade Agreement - NAFTA - which greatly facilitates U.S.-Mexico trade. Of these three advantages, proximity to U.S. markets is unique to Mexico; which basically rules out the possibility that another Latin American country will develop an export-of-manufactures sector similar to the one that Mexico has developed. Hence, as the U.S. economy grows, the exports of manufactures of Latin America to the U.S. are likely to grow; but such growth will be constrained by how economically convenient it is for companies from the U.S, Europe, Japan, India and China - that export to the U.S. - to manufacture and/or assemble some of these exports in Mexico

\section{EXPORTS OF U.S. GOODS TO LATIN AMERICA}

Exports of U.S. goods to Latin America grew between 2001 and 2010 at an annual rate of $7.2 \%$ - from $\$ 152.9$ billion to $\$ 286.1$ billion. For the same period, Latin America's GDP grew at an annual rate of $3.5 \%$. These figures indicate that U.S. exports to Latin America grew at a vigorous pace during these years. Such vigorous growth was, however, accompanied by a decline in the share or percentage of U.S. goods in Latin American imports. In 2001, U.S. exports to Latin America represented 44\% of the goods that Latin America imported; but by 2010, the percentage of U.S. goods in Latin American imports had declined to 34\% (ECLAC, 2010; CIA, 2011; and U.S. Census Bureau, 2011)

The main cause of the relative decline of the U.S. as exporter of goods to Latin America was the rapid growth of exports from China to these nations, especially to Brazil and Mexico. Chinese exports to this region grew from less than $\$ 2$ billion in 2001 to at least $\$ 85.3$ billion in 2010. That is, between 2001 and 2010, China's exports to Latin America went from representing $0.57 \%$ to representing $10.2 \%$ of Latin American imports (Kay and CanaveriBacarreza, 2011, and CIA, 2011).

The rapid growth of Chinese exports to Latin America may have displaced few U.S. products, like solar panels, from Latin American markets. However, such displacement - if it occurred - was quite marginal since the majority of Chinese exports to Latin America consisted of plastic toys, inexpensive shoes, mechanical tools, cheap textiles, cell-phones, and low-tech industrial machinery, which are goods that have not been manufactured in the U.S. in several decades.

A second important contributor to the relative decline of the U.S. as exporter to Latin America was the direct dependence of U.S. exports of intermediate goods from U.S. economic growth. This dependence was, and continuous to be, through Mexico's export-of-manufactures sector which, as already mentioned, uses imported intermediary goods to assemble and manufacture appliances, cars, complex chemical inputs, and other high-income goods that are exported back to the U.S. In 2001, this sector received, according to figures from Mexico's central bank, approximately $85 \%$ of the U.S. exports to Mexico, which represented close to $25 \%$ of all Latin American imports. As the U.S.'s GDP grew at an average of 5.4\% per year between 2001 and 2006, U.S. exports of intermediary goods to Mexico grew 5.7\% per year; but as the rate of expansion of the U.S.'s GDP declined to an average of $1.4 \%$ between 2007 and 2010, the yearly growth of U.S. exports of intermediary declined to 5\% per year. Thus, by 2010, U.S. exports of intermediary goods represented $16 \%$ of all Latin American imports (U.S. Census Bureau, 2011, and Banco de Mexico, 2011). 
The third possible major cause of the relative decline of the U.S. as exporter to Latin America was what may be called a good, albeit insufficient, response of U.S. exports of finished goods to the positive economic developments that took place across most of Latin America during the period 2001-2010. Between 2001 and 2010, as mentioned above, Latin America's GDP grew at an annual rate of 3.5\%. At the same time, with the exception of Cuba and Venezuela, the Latin nations reduced - slowly but steadily - their tariffs and other protectionist measures. As a result of these positive economic developments, U.S. exports of consumer and capital goods to Latin America expanded $9.16 \%$ per year - from $\$ 66.8$ billion in 2001 to $\$ 147.1$ billion in 2010 . Yet, between 2001 and 2010, the percentage of Latin American imports that corresponded to U.S. finished goods still declined - from 19.2\% to 17.6\% (Banco de Mexico, 2011, and U.S. Census Bureau, 2011)

Given the economic progress that most Latin nations experienced between 2001 and 2010, it is very likely that - aside from Venezuela and Cuba - these nations will continue implementing economic policies that keep inflation at very low levels, reduce public deficits, gradually - but steadily - open the economy and increase the efficiency of their infrastructures (Hornbeck, 2010). The continued implementation of these types of policies may not cause Latin America's GDP to grow at $3.5 \%$ or Latin imports to grow at $10.2 \%$ per year as they did during the 2001-2010 period. However, these policies are very likely to continue generating the expansion of the demands for capital goods and for high-income consumer goods in these nations. This means that U.S. exports of high-income and capital goods to Latin America have the opportunity to grow at high rates since these kinds of goods are produced in the U.S. at competitive prices.

This optimistic outlook faces, however, some serious obstacles. The first is competition from European and Japanese luxury products. Expensive Japanese cars and electronics, as well as all kinds of high-income European goods, are already easy to find in Latin American countries. In fact, between 2003 and 2010, European goods maintained their 15\% share in Latin American imports (Eurostat, 2011). Hence, as the economies of the Latin countries grow, Japanese and European producers of high-income goods will try to increase their presence in the consumer and producer markets of these countries. This means that competition will be awaiting the U.S. producers of luxury goods who decide to enter Latin American.

A second obstacle is the tariffs that Argentina and Brazil continue to impose on U.S goods. Brazil and Argentina have the first and third largest economies, respectively, of Latin America. They generate between $42 \%$ and $45 \%$ of the GDP of Latin America and no less than 65\% of the GDP of South America. Therefore, these tariffs, albeit quite small, are reducing the potential demands for U.S. goods in the largest consumer and producer markets of South America. These tariffs could be eliminated if the U.S. government were willing to eliminate its domestic agricultural subsidies, since this is what Brazil and Argentina have requested in order to start negotiating a free trade agreement with the U.S. (Hornbeck, 2010). However, given that such subsidies constitute a delicate political issue, it is unlikely that U.S. products will gain duty-free entrance - any time soon - to the largest markets of South America.

A third obstacle to the rapid growth of U.S. exports of goods to Latin America is the disdain of Latin America across U.S. society (Coelen, 1998). This disdain not only deters potential U.S. exporters from entering Latin American markets, but since it is well known in Latin countries, this disdain also adds obstacles to the U.S. exporters that are already doing business in Latin America.

\section{IMPLICATION FOR THE U.S.: EROSION OF INFLUENCE}

For decades the U.S. has been the country with the most economic and political influence on Latin America. Given this background, it seems reasonable to expect that as the decline in the relative importance of the U.S. as trading partner of Latin America continues, the governments of the Latin nations are likely to give more weight to their political convictions and economic interests than to the need to avoid conflicts with the U.S. in their decisions to support, oppose, or ignore U.S. international initiatives. That is, as the U.S. has become a less important trading partner of Latin America, it seems reasonable to expect some erosion of the influence that the U.S. has had across Latin America. This reasoning - although appealing - is not, as argued below, entirely correct.

As already mentioned, there are 19 countries in Latin America. One of these nations - Cuba - has very little relevance in international trade affairs because it has an economy that is practically closed. Of the other 18 Latin 
American nations, 11 have signed free trade treaties with the U.S. (U.S. Free Trade Agreements, 2012). In alphabetical order, they are Chile, Colombia, Costa Rica, El Salvador, Guatemala, Honduras, Mexico, Nicaragua, Panama, Peru, and the Dominican Republic. These treaties have been criticized - for a variety of reasons - in each one of these 11 Latin nations and in the U.S. Nonetheless, these treaties preclude - or at least minimize - the possibility of trade sanctions imposed as a consequence of disagreements about non-trade issues. Despite this protection, the following countries still have to be rather cautious in their reactions to international initiatives of the U.S.: Colombia, Mexico, and the members of the Dominican Republic-Central American Free Trade Agreement the CAFTA - signed in 2008; namely, Costa Rica, Guatemala, Honduras, Nicaragua, El Salvador and the Dominican Republic.

Two factors are the cause of this extra caution. First, all of these nations are still very dependent from the U.S. for their exports and imports since at least $70 \%$ of their total trade continues to be with the U.S. Second, with the exception of Costa Rica, these nations have sent - and continue to send - large numbers of illegal immigrants to the U.S., and although the deportation of all of these immigrants is very unlikely, enough of them could be deported to greatly aggravate the unemployment problems in their respective home countries. Additionally, for Colombia and Mexico, the illegal drug trade that afflicts these nations imposes a solid constraint to their responses to international initiatives of the U.S. Hence, of the 11 nations that have signed a free trade agreement with the U.S., the only countries where the political and economic influence of the U.S. may have been eroded in the last ten years are Chile, Panama, and Peru.

This erosion, however, has been noticeable in the seven Latin countries that have decided not to sign free trade agreements with the U.S. Of these nations, Venezuela, Bolivia, and Ecuador have exchanged hostile rhetoric with the U.S. and have also taken actions that go against the political and economic interests of the U.S. Of these actions the most noticeable have been those taken by Venezuela, which include establishing a political alliance with Iran, buying weapons from Belarus, criticizing any Latin American country that cooperates with the U.S., and forming the Bolivarian Alternative to the Americas - ALBA - which is an organization that has the explicit goal of opposing the Free Trade Area of the Americas - the FTAA - proposed by the U.S (Hornbeck, 2010).

The anti-U.S. behavior of Venezuela, Bolivia, and Ecuador began in 1999, 2006, and 2007, respectively, which were the years when Hugo Chavez of Venezuela, Evo Morales of Bolivia, and Rafael Correa of Ecuador were elected presidents of their respective countries. Since they were presidential candidates, Correa - but especially Morales and Chavez - have openly expressed their socialist convictions and their opposition to international initiatives of the U.S. that were, from their perspective, contrary to their ideologies. Within Venezuela, Chavez has shown his socialist convictions by greatly increasing the role of the government at the expense of the private sector (CIA, 2011). This background suggests that the political ideology of Presidents Chavez, Morales, and Correa rather than less trade, in percentage terms, with the U.S. is what has caused the erosion of U.S. influence in these three nations.

Argentina, Brazil, Paraguay, and Uruguay - the four original members of the Mercosur customs union - are the other South American nations that do not have a free trade agreement with the U.S. These nations, under the leadership of Brazil, have made it clear that as long as the U.S. government refuses to eliminate its domestic agricultural subsidies, they will not support trade initiatives of the U.S., like the Free Trade Areas of the Americas the FTAA. The opposition of Brazil and Argentina to U.S. trade initiatives has coincided with the drastic growth in trade between these nations and China, the EU, and other Latin American nations. In fact, China has become Brazil's main trading partner and Argentina's second importer (Kay and Canaveri-Bacarreza, 2011). The opposition to U.S trade initiatives has not, however, been accompanied by anti-U.S. rhetoric from the presidents of Brazil, Argentina, Paraguay, or Uruguay, nor have any of these four nations entered into political alliances with Iran or with any other country that is openly hostile to the U.S. These arguments suggest that the opposition of Brazil, Argentina, Paraguay, and Uruguay to the trade initiatives of the U.S. is based upon economic rather than ideological reasons. Hence, for these four nations, the decline - in percentage terms - of their trade in goods with the U.S. may have helped to reduce the economic influence that the U.S. used to have on these nations. 


\section{CONCLUSIONS}

The expected slow growth of the U.S. economy and, most importantly, the very limited capacity of Latin America to manufacture high-income goods will preclude the fast growth of U.S. imports from this region. Thus, the percentage of Latin American exports that go to the U.S. should continue declining.

The percentage of U.S. products, U.S. exports, in Latin American imports is also expected to continue its decline. This decline, however, not only can be avoided, but it can actually be reversed if the U.S. government and potential U.S. exporters actively promote U.S. exports to Latin America. This may also help to reduce the trade deficit with Latin America and the excess capacity that afflicts the U.S. economy. Promoting the rapid growth of U.S. exports to Latin America is not, however, an easy task since it requires removing the negative image that Latin America has across U.S. society.

The decline of the relative importance of the U.S. as a trading partner of Latin America has contributed to the erosion of U.S. influence in this region. Thus, such erosion will increase if the relative importance of the U.S. as a trading partner of Latin America continues declining. This does not imply that English will be displaced as the foreign language that is taught in the schools in Latin America; nor does it imply that Latin American students that would have come to the U.S. to obtain an advance degree will be going to China or Europe to obtain that degree. What this decline implies is that the U.S government cannot take for granted, as in decades past, the support of the Latin American nations of its international initiatives. This decline also implies that among consumers, producers and government agencies, from Mexico to Argentina, there is full awareness that the U.S. is neither the sole buyer of their goods nor the sole supplier of high-income and high-tech consumer and capital goods.

\section{AUTHOR INFORMATION}

Rutilio Martinez is an associate professor of statistics and international business at the Monfort College of Business of the University of Northern Colorado. He has written several papers about the economies of Latin America and has taught, in Germany, Lithuania and the Czech Republic, a class that deals with the economies and managerial cultures of Latin America. E-mail: rutilio.martinez@unco.edu (Corresponding author)

Vish Iyer is a professor of marketing at the Monfort College of Business of the University of Northern Colorado. He has published more than 20 papers. He organizes and leads a popular yearly student trip to Europe. He has also been in charge of a federally supported academic exchange agreement that includes six universities - two in Canada, two in the U.S.A. and two in Mexico.

\section{REFERENCES}

1. Banco de Mexico. (2011). Balanza de Pagos. Retrieved July 5, 2012 from http:www.banxico.org.mx

2. Central Intelligence Agency, CIA. (2011). The World Factbook. Retrieved July 5, 2012 from http://www.cia.gov/library/publications/the world factbook/geoes/ar.html

3. Coelen, S.P. (1998). The Importance of Latin America to U.S. International Trade. Massachusetts Institute for Social and Economic Research. University of Massachusetts at Amherst. Retrieved September 22 from http://www.umass.edu/miser/laimpall.pdf

4. Economic Commission for Latin American and the Caribbean, ECLAC. (2010). Statistical Yearbook of Latin America and the Caribbean. Retrieved September 5, 2011 from http://website.eclac.cl/anaurio_2010/docs/Anuario Estadístico_2010.pdf

5. Eurostat. (2011). EU-27 Export of goods to selected Latin American countries between 2003 and 2010 and EU-27 Import of goods to selected Latin American countries between 2003 and 2010. Retrieved September 13, 2011 from http://epp.eurostat.ec.europa.eu/statistics explained/index.php

6. Hornbeck, J.C. (2010). Latin American Trade: Recent Trends and Policy Issues. Congressional Research Service. Retrieved September 5, 2011 from www.nationalaglawcenter.org/ assets/ars 698-840 pdf

7. Kay, J.S. and Canavire-Bacarreza, G. (2011). Trade Strengths Ties between China and Latin America. EconSouth Federal Reserve Bank of Atlanta: Second Quarter (pp14-19). 
8. U.S Census Bureau. (2011). Foreign Trade U.S. Trade in Goods and Services by Country. Retrieved September 6, 9 and 10, 2011 from http://www.census.gov/foreign trade/balance/c3570.html\#2010

9. U.S. Free Trade Agreements. (2012). Helping U.S. Companies Export. Retrieved September 17, 2012 from http://export.gov/fta/

10. U.S. Government Printing Office, GPO. (2011). Economic Report of the President. Retrieved July 9, 2012 from http://www.gpo.gov/fdsys/prg/ERP.2011 
NOTES 